University of Nebraska - Lincoln

DigitalCommons@University of Nebraska - Lincoln

Faculty Publications from the Harold W. Manter Laboratory of Parasitology

1964

\title{
The Seasonal Cycle of Abundance of Echinococcus multilocularis in Naturally Infected Arctic Foxes
}

Francis H. Fay

Arctic Health Research Center

Robert L. Rausch

Arctic Health Research Center, rausch@u.washington.edu

Follow this and additional works at: https://digitalcommons.unl.edu/parasitologyfacpubs

Part of the Parasitology Commons

Fay, Francis H. and Rausch, Robert L., "The Seasonal Cycle of Abundance of Echinococcus multilocularis in Naturally Infected Arctic Foxes" (1964). Faculty Publications from the Harold W. Manter Laboratory of Parasitology. 596.

https://digitalcommons.unl.edu/parasitologyfacpubs/596

This Article is brought to you for free and open access by the Parasitology, Harold W. Manter Laboratory of at DigitalCommons@University of Nebraska - Lincoln. It has been accepted for inclusion in Faculty Publications from the Harold W. Manter Laboratory of Parasitology by an authorized administrator of DigitalCommons@University of Nebraska - Lincoln. 


\title{
THE SEASONAL CYCLE OF ABUNDANCE OF ECHINOCOCCUS MULTILOCULARIS IN NATURALLY INFECTED ARCTIC FOXES
}

\author{
F. H. FAY and R. L. RausCH \\ Zoonotic Disease Section, Arctic Healtb Researcb Center \\ U. S. Department of Health, Education and Weltare, Public Health Service \\ Anchorage, Alaska (U.S.A.)
}

In some preliminary work on the ecology of Ecbinococcus multilocularis (Rudolphi, 1801) on St. Lawrence Island, Alaska, Rausch and Schiller (1956. Parasitology, 46 (3\&4):395-419) noted that the percentage of arctic foxes, Alopex lagopus Linnaeus, harboring the adult cestodes seemed to vary annually in direct relation to the population density of tundra voles, Microtus oeconomus innuitus Merriam, the principal intermediate host. With the primary objective of examining this relationship in greater detail, an intensive, long-term ecologic investigation was begun on this island in 1955. Some of the results in the first 7 years are reported here. 
Samples of foxes and voles were collected periodically to determine the status of their populations and the incidence, respectively, of adult and larval E. multilocularis. Infection rates in both hosts were found to be seasonally cyclic. In the foxes (1169 specimens) the peak infection rate of about 90 per cent occurred in autumn and the trough of about 30 per cent occurred in the spring. This cycle was apparently the result of regular seasonal changes of diet, plus the relatively short life-span of the adult cestode. The quantity of voles eaten varied with their availability, which was greatest in summer and autumn and least in winter and spring. In the voles ( 2795 specimens) the infection rate was highest in spring and lowest in summer and was directly related to age composition of the population. The infection rate of voles was found to increase logarithmically with age.

Using the largest monthly samples (December) as the basis for annual comparison, the infection rates of the foxes were found to have been nearly uniform from 1955 to 1961 , with a mean of about 83 per cent. Minor annual variations during this period were correlated with age composition of the samples, rather than with population density per se of either host. The adult foxes were infected about 10 per cent less than their 6-month-old young. The infection rates of December samples in 1950 to 1954 also were found not to differ from the 1955-61 mean. The large differences that had been reported earlier were due principally to uneven sampling of the seasonal cycle, rather than to any major annual changes in abundance. 